\title{
We are what we repeatedly do.
}

\author{
Só fazemos melhor aquilo que \\ repetidamente insistimos em melhorar...
}

(Aristoteles, 384-322 BC.)

A bout a year ago, Revista Brasileira de Oftalmologia (RBO) started publishing most of its editions in the Ahead of Print form, in which the journal is available electronically on the website of Sociedade Brasileira de Oftalmologia (SBO) before the distribution of the printed version. The disclosure is made approximately one month before the normal deadline. In this advanced publication profile we have increased agility and editorial dynamism, enabling early access to the latest research and the possibility of citation of the scientific papers earlier.

The review of scientific articles that is traditionally made by Peer Review by means of analysis with two different revisers is also being made in the Fast Track mode. The vast majority of articles submitted for publication in RBO has an initial acceptance or rejection response within 60 days. The decrease in time of up to 6 months allows authors to go on with their research or choose to send the article to another journal, not interrupting their scientific production at the expense of a slower submission process.

Currently the need for researchers to be regularly publishing is directly related to the scientific production of postgraduate courses, which is one of the main criteria of CAPES for assessment and conceptualization. There is no original articles prior to 2016, and all received from now on have publication forecast at the same year they are sent, mainly depending on the changes requested by the revisers and their correction by the authors. Publishing an article faster increases the chances of originality, linking the pioneering research conducted, and generating further discussion related to the article and greater number of citations.

The international co-participation is higher after the renewal of the international editorial board, as well as scientific partnerships. It is estimated that today about $30 \%$ of the total number of articles submitted have revisions made by international revisers, and $20 \%$ of all articles published in the last year came from various continents (America, Europe and Asia).

We recently reached for the first time in RBO over 35,000 accesses per month by the website SciELO, with a real increase of approximately $39 \%$ in relation to access in previous years. The greatest search was for original articles $(72 \%)$; however, the most accessed article last year was the one about the review of the paralysis of the sixth nerve, published in January/February 2013. Of all articles submitted for publication in about a year $40 \%$ failed in the first analysis. All these statistics demonstrate the transformation that RBO has undergone over the past director ships, improving their quality scores and being established as a scientific journal of relevance and influence on national and international levels.

Excellence, then, is not an act, but a habit.

(Aristoteles, 384-322 BC.)

André Luis Freire Portes

Associate Professor of Ophthalmology in the Medicine

School at Universidade Estácio de Sá (UNESA- RJ)

Doctor in Sciences of the Ophthalmology Programin the Medicine

School at Universidade de São Paulo (USP-SP)

Editor-in-chief of Revista Brasileira de Oftalmologia (2015-2016)

\section{REFERENCES}

1. Scielo. http://analytics.scielo.org/w/accesses?journal=0034-7280\&collection=scl.Retrieved May 31, 2016, fromhttp://www.scielo.br

2. SCImago. (2007). SJR - SCImagoJournal\& Country Rank. Retrieved May 31, 2016, fromhttp://www.scimagojr.com

3. Curi RLN, Costa ICBO, Barroso TGM. Paralisia do VI nervo (abducente). RevBras Oftalmol. 2013; 72 (1): 59-69 